\title{
PENERAPAN MODEL PEMBELAJARAN DISCOVERY BERBANTUAN \\ BULETIN UNTUK MENINGKATKAN KEMAMPUAN BERPIKIR LOGIS
}

\author{
Harto Nuroso, Wawan Kurniawan, Cicik Setyawati \\ Program Studi Pendidikan Fisika FPMIPATI Universitas PGRI Semarang
}

\begin{abstract}
Abstrak
Telah dilakukan penelitian quasi-eksperimen yang bertujuan untuk mengetahui pengaruh model pembelajaran discovery berbantuan buletin terhadap kemampuan berpikir logis siswa kelas XI MIPA SMA N 1 Cepu. Sampel penelitian dipilih dengan menggunakan teknik cluster random sampling sehingga diperoleh kelas XI MIPA 4 sebagai kelas control dan XI MIPA 5 sebagai kelas eksperimen yang masing-masing kelas berjumlah 36 siswa. Pengambilan data penelitian menggunakan tes hasil belajar kognitif berupa soal uraian yang dibuat berdasarkan indikator kemampuan berpikir logis. Berdasarkan analisis uji $t$ diketahui nilai $t_{\text {hitung }}$ sebesar 6,267 dan $t_{\text {tabel }}$ sebesar 1,667. Karena $t_{\text {hitung }}$ lebih besar dari pada $t_{\text {tabel }}$ maka hipotesis nol ditolak, sehingga diketahui bahwa model pembelajaran discovery berbantuan buletin berpengaruh terhadap kemampuan berpikir logis siswa. Dari analisis keempat indikator kemampuan berpikir logis, diketahui bahwa pengaruh paling tinggi model pembelajaran discovery berbantuan buletin terdapat pada indikator ke-empat yaitu silogisme, sedangkan pengaruh paling rendah terdapat pada indikator ke-3 yaitu kondisional.
\end{abstract}

Kata kunci : model pembelajaran discovery, buletin fisika, berpikir logis 


\section{PENDAHULUAN}

Idealnya dalam suatu proses pembelajaran selalu membandingkan menganalisis serta menghubungkan pengetahuan satu dengan pengetahuan lainnya (Mundiri, 2008). Fisika merupakan mata pelajaran yang dalam prosesnya diterapkan tiga fase belajar pengetahuan menurut Piaget salah satunya yaitu fase pengenalan konsep (Dimyati \& Mudjiono, 2009). Pada fase pengenalan konsep dibutuhkan kemampuan berpikir logis dimana siswa sendiri yang melakukan penalaran melalui seleksi dan organisasi pengalaman serta mengintegrasikannya dengan apa yang telah diketahui sehingga dapat terbentuk suatu konsep yang matang (Romauli, 2013).

Fakta pembelajaran di SMA N 1 Cepu menggunakan pembelajaran konvensioal dimana guru berperan sebagai pusat pembelajaran. Siswa hanya menerima begitu saja informasi yang diberikan oleh guru dan mereka tidak perlu mencari informasi dari sumber-sumber lain yang relevan sehingga siswa tidak terlibat aktif dalam proses pembelajaran. Ini mengakibatkan kemampuan berpikir logis siswa rendah. Berdasarkan penelitian yang telah dilakukan oleh Mika Romauli, siswa yang memiliki kemampuan berpikir logis rendah merasa sulit memahami penjelasan guru tanpa disertai dengan gambar dan terganggu konsentrasinya saat melihat tampilan yang menurut mereka kurang menarik (Romauli, 2013).

Kurikulum 2013 lebih menekankan kemampuan berbahasa sebagai alat komunikasi pembawa pengetahuan dan berfikir logis, sistematis, dan kreatif. Oleh karena itu diperlukan model pembelajaran yang membantu siswa untuk berpikir logis sehingga siswa dapat menemukan konsep yang benar. Pembelajaran yang membuat siswa aktif dalam proses pembelajaran serta dapat meningkatkan kemampuan berpikir logis siswa adalah model pembelajaran discovery (Widiadnyana, Suastra, \& Sadia, 2014). Menurut Jerome Bruner pembelajaran discovery adalah metode yang mendorong siswa untuk mengajukan pertanyaan dan menarik kesimpulan dari prinsip-prinsip umum praktis contohnya pengalaman (Hosnan, 2014). Maka dapat dilihat bahwa model pembelajaran discovery akan berbeda dengan model pengajaran langsung seperti yang sering diterapkan. Dengan perbedaan-perbedaan antara model pembelajaran discovery dan model pengajaran langsung diyakini memberikan efek yang berbeda terhadap kemampuan berpikir logis siswa. Pembelajaran discovery akan semakin efektif apabila dibantu dengan suatu media pembelajaran yang menarik. Salah satu media pembelajaran yang menarik yaitu buletin fisika. Berdasarkan pengembangan media yang dilakukan oleh Yulian Adi Setyono, Sukarmin \& Wahyuningsih, buletin fisika 
merupakan media pembelajaran yang memiliki kriteria baik ditinjau dari minat baca siswa (Setyono, Sukarmin, \& Wahyuningsih, 2013).

Oleh karena itu, untuk meningkatkan hasil belajar siswa dapat digunakan model pembelajaran discovery berbantuan buletin yang dapat melibatkan siswa dalam proses pembelajaran secara langsung, sehingga diharapkan siswa dapat mengembangkan kemampuan berpikir logis untuk menemukan konsep dari materi yang sedang dipelajari.

\section{METODE PENELITIAN}

Penelitian ini dilaksanakan di SMA N 1 Cepudengan sampel kelas XI MIPA 4 sebagai kelas kontrol dan kelas XI MIPA 5 sebagai kelas eksperimen. Desain yang digunakan adalah Quasi Eksperimental dengan bentuk design "Nonequivalent Control Group Design" (Sugiyono, 2012). Pemilihan sampel menggunakan teknik cluster random sampling yaitu dipilih secara acak berdasarkan kelas. Variabel dalam penelitian ini yaitu model pembelajaran discovery berbantuan buletin (variabel bebas) dan kemampuan berpikir logis siswa (variabel terikat). Instruman yang digunakan berupa tes uraian dan dibuat berdasarkan indikator kemampuan berpikir logis. Teknik analisis data pada penelitian ini yaitu, uji ketercapaian indikator kemampuan berpikir logis, uji hipotesis, dan uji gain. Analisis data akhir dilakukan menggunakan analisis uji t satu pihak. Uji t digunakan untuk menguji hipotesis, sedangkan uji gain digunakan untuk mengetahi besarnya peningkatan kemampuan berpikir logis siswa setelah diberi perlakuan. Data yang digunakan untuk uji t dan uji gain yaitu nilai posttest siswa.

\section{HASIL DAN PEMBAHASAN}

Berdasarkan analisis validitas, reliabilitas, daya pembeda dan taraf kesukaran,instrumen yang dibuat oleh peneliti dapat dikatakan layak untuk mengukur kemampuan berpikir logis siswa. Analisis kemampuan awal siswa dalam berpikir logis berdasarkan nilai pretest pada kedua kelas yang terpilih sebagai sampel dapat dilihat pada tabel 1 .

Uji t satu pihak diperoleh $t_{\text {hitung }}=6,267$. Pada tabel distribusi $t$, untuk nilai $\alpha=0,05$ dan nilai $\mathrm{dk}=70$, diperoleh $\mathrm{t}_{\text {tabel }}=1,667$. Jadi ada pengaruh model pembelajaran discovery berbantuan buletin terhadap kemampuan berpikir logis siswa. Grafik perbandingan pretest dan posttest pada kelas eksperimen dan kontrol dapat dilihat dari grafik berikut.

Dari grafik gambar 1, untuk kelas eksperimen didapatkan nilai rata-rata pretest yaitu 26 dan rata-rata posttest yaitu 70 sehingga diperoleh nilai gain untuk kelas eksperimen sebesar 0,60 dikategorikan sedang. Sedangkan pada kelas kontrol didapatkan nilai rata-rata pretest 
yaitu 27 dan rata-rata posttest yaitu 55 sehingga diperoleh nilai gain untuk kelas kontrol sebesar 0,39 dikategorikan sedang. Hasil uji $\mathrm{N}$-gain menunjukkan bahwa rata-rata hasil belajar siswa pada kelas eksperimen dan kelas kontrol mengalami peningkatan dan peningkatannya dapat dilihat pada grafik gambar 2 .

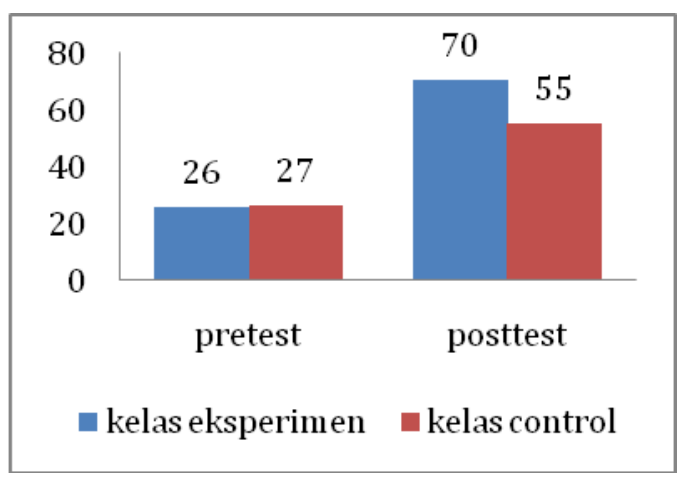

Gambar 1. Grafik perbandingan hasil pretest dan posttest kelas eksperimen dan kontrol

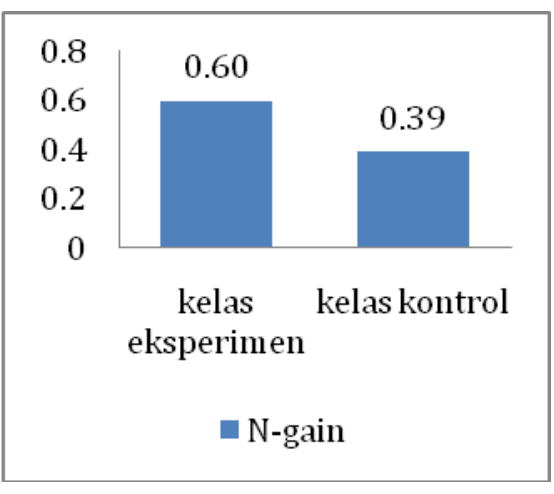

Gambar 2. Grafik perbandingan peningkatan hasil belajar

Hasil analisis tiap-tiap indikator kemampuan berpikir logis pada hasil pretest dan posttest kelas eksperimen dan kelas kontrol yaitu sebagai berikut :

Tabel 1. Hasil analisis kemampuan awal (Pretest)

\begin{tabular}{ccccc}
\hline Kelas & Analogi & Generalisasi & Kondisional & Silogisme \\
\hline Eksperimen & $27 \%$ & $47 \%$ & $36 \%$ & $20 \%$ \\
Kontrol & $31 \%$ & $44 \%$ & $30 \%$ & $22 \%$ \\
\hline
\end{tabular}

Tabel 2. Hasil analisis kemampuan akhir (Posttest)

\begin{tabular}{ccccc}
\hline Kelas & Analogi & Generalisasi & Kondisional & Silogisme \\
\hline Eksperimen & $60 \%$ & $71 \%$ & $53 \%$ & $77 \%$ \\
Kontrol & $50 \%$ & $73 \%$ & $52 \%$ & $52 \%$ \\
\hline
\end{tabular}

Dari tabel 1 dan 2 di atas dapat diketahui adanya peningkatan pada tiap-tiap indikator kemampuan berpikir logis yang signifikan antara sebelum diberi perlakuan dan sesudah diberi perlakuan. Indikator pertama yaitu analogi, mengukur kemampuan siswa dalam menentukan kesamaan hubungan antara peristiwa satu dengan peristiwa lainnya. Kemampuan menganalogi siswa setelah diberi perlakuan yang berbeda pada masing-masing kelas 
mengalami peningkatan, pada kelas eksperimen kemampuan menganalogi meningkat sebesar $33 \%$ sedangkan pada kelas kontrol meningkat sebesar 19\%. Peningkatan kemampuan menganalogi yang berbeda antara kelas eksperimen dan kelas kontrol bergantung pada pengalaman dan pengetahuan yang dimiliki oleh masing-masing siswa sehingga mereka mampu membandingkan, mencari kesamaan dan hubungan antara dua hal yang berbeda. Rendahnya peningkatan kemampuan berpikir logis siswa pada kelas kontrol dikarenakan informasi dan pengalaman yang mereka dapatkan selama proses pembelajaran kurang.

Indikator kedua yaitu generalisasi, mengukur kemampuan siswa dalam menarik kesimpulan yang berlaku untuk umum. Terdapat peningkatan kemampuan siswa dalam menarik kesimpulan umum setelah diberi perlakuan, baik siswa pada kelas eksperimen maupun kelas kontrol. Kemampuan menarik kesimpulan secara umum setelah diberi perlakuan pada kelas kontrol lebih tinggi 2\% jika dibandingkan dengan kelas eksperimen. Ketercapaian indikator kedua pada masing-masing kelas yang menjadi sampel lebih dari $50 \%$, ini berarti penggunaan model pembelajaran discovery cukup mempengaruhi kemampuan siswa dalam menarik kesimpulan umum. Tetapi penggunaan media pembelajaran buletin tidak berpengaruh terhadap kemampuan siswa dalam menarik kesimpulan umum, dibuktikan dengan peningkatan kemampuan mengeneralisasi kelas kontrol lebih tinggi dibandingkan dengan kelas eksperimen. Kemampuan mengeneralisasi dipengaruhi oleh pengamatan fakta, menangkap struktur pokok, pola dan prinsip umum dari data yang disajikan.

Indikator ketiga yaitu kondisional, mengukur kemampuan siswa dalam menarik kesimpulan dari pernyataan-pernyataan yang berbentuk argumen. Pada kelas eksperimen maupun kelas kontrol terjadi peningkatan kemampuan kondisional siswa setelah diberi perlakuan. Peningkatan pada masing-masing kelas menunjukkan bahwa penggunaan model pembelajaran discovery cukup memberikan pengaruh pada kemampuan siswa dalam menarik kesimpulan dari pernyataan-pernyataan berbentuk argumen. Kemampuan kondisional siswa setelah diberi perlakuan pada kelas eksperimen lebih tinggi $1 \%$ jika dibandingkan pada kelas kontrol. Tingginya peningkatan kemampuan kondisional siswa pada kelas eksperimen karena pada media buletin siswa dilatih untuk memilih informasi yang layak untuk digunakan. Sehingga siswa mampu membedakan mana argumen yang benar dan mana argumen yang salah dan kemudian dapat menyimpulkan dengan baik dan benar.

Indikator terakhir yaitu silogisme, mengukur kemampuan siswa dalam menarik kesimpulan dari pernyataan-pernyataan berbentuk hipotesis dan berbentuk kuantifikasi. 
Kemampuan silogisme setelah diberi perlakuan pada kelas eksperimen lebih tinggi $25 \%$ dari kelas kontrol, dengan kata lain penggunaan media pembelajaran berupa buletin berpengaruh cukup tinggi terhadap kemampuan silogisme siswa. Tingginya kemampuan silogisme siswa kelas eksperimen dikarenakan media pembelajaran buletin memberikan informasi berupa hipotesis yang telah dianalisis sehingga siswa mampu menyimpulkan dengan baik. Presentase tiap-tiap indikator pada kelas eksperimen maupun kelas kontrol dapat dilihat pada tabel berikut.

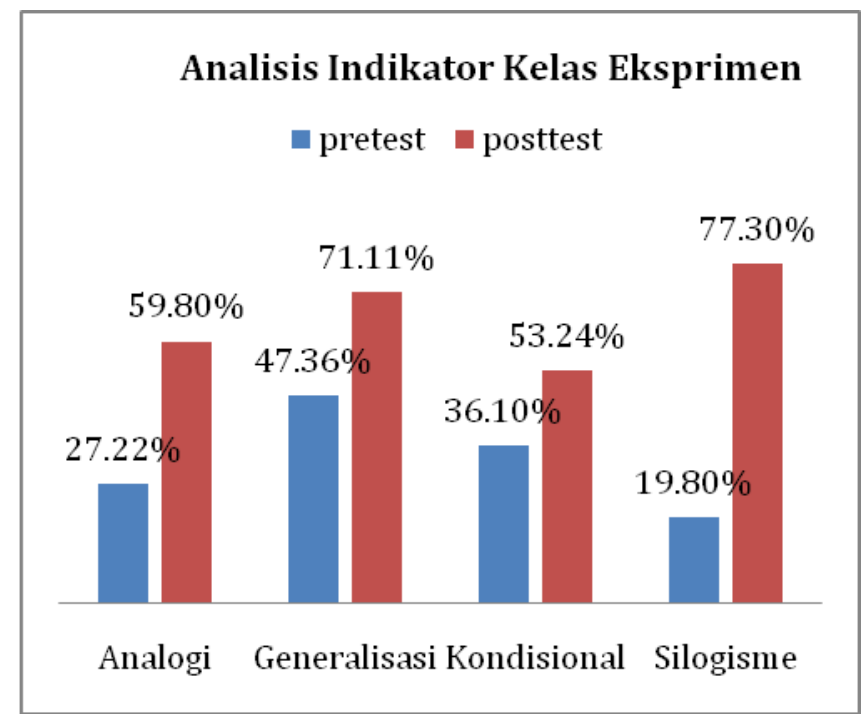

Gambar 3.Grafik indikator kelas eksperimen

Berdasarkan hasil yang telah diperoleh dari analisis pada kelas eksperimen dan kelas kontrol, terdapat perbedaan hasil belajar yang signifikan. Pada kelas eksperimen yang diajar menggunakan model pembelajaran discovery berbantuan buletin terbukti memberikan kontribusi terhadap peningkatan hasil belajar kognitif siswa berdasarkan uji-t. Perbedaan ini disebabkan oleh penggunaan media yang sangat membantu siswa untuk meningkatkan hasil belajar, hal ini karena media pembelajaran berupa buletin fisika termasuk kriteria baik ditinjau dari minat baca siswa (Setyono, Sukarmin, \& Wahyuningsih, 2013). Dilihat dari besarnya presentase pengaruh penggunaan model pembelajaran discovery berbantuan buletin terhadap peningkatan hasil belajar pada kelas eksperimen, menunjukkan bahwa tingginya hasil belajar siswa tidak sepenuhnya dipengaruhi oleh penerapan model pembelajaran discovery berbantuan buletin.

Tahapan pembelajaran discovery yang pertama yaitu siswa dihadapkan pada sesuatu yang memberikan kebingungan, pada tahap ini guru mengajukan pertanyaan pada siswa agar timbul rasa ingin tahu siswa. Tahapan selanjutnya yaitu problem statement dimana guru 
memberikan kesempatan kepada siswa untuk mengidentifikasi masalah sehingga dapat terbentuk hipotesis. Tahapan ketiga yaitu data collection (pengumpulan data), siswa diberi kesempatan untuk mengumpulkan informasi-informasi yang relevan dengan materi yang sedang dipelajari baik secara praktik maupun media pembelajaran yang lain. Tahapan keempat yaitu data processing dimana semua informai hasil bacaan, wawancara, observasi, dan sebagainya, semuanya diolah, diacak, diklasifikasikan, ditabulasi, bahkan bila perlu dihitung dengan cara tertentu serta ditafsirkan pada tingkat kepercayaan tertentu. Tahapan selanjutnya yaitu verification (pembuktian), siswa melakukan pemeriksaan secara cermat untuk membuktikan benar atau tidaknya hipotesis yang ditetapkan pada tahap problem statement. Tahapan terakhir yaitu generalization (menarik kesimpulan umum) dimana siswa bersama guru menarik kesimpulan yang dapat dijadikan prinsip umum dan berlaku untuk umum (Priyatni, 2014).

\section{KESIMPULAN}

Berdasarkan hasil penelitian yang telah dilakukan, dapat ditarik kesimpulan bahwa terdapat pengaruh model pembelajaran discovery berbantuan buletin terhadap kemampuan berpikir logis siswa SMA N 1 Cepu. Hal tersebut dapat dilihat dari perbedaan hasil rata-rata nilai pretest dan posttest setelah dilakukan uji t dan uji gain pada kelas eksperimen dan kelas kontrol. Peningkatan tertinggi pada masing-masing kelas terdapat pada indikator ke-4 yaitu silogisme, sedangkan peningkatan paling rendah pada masing-masing kelas terdapat pada indikator ke-3 yaitu kondisional. Penggunaan model pembelajaran discovery berbantuan buletin sangat cocok digunakan untuk meningkatkan kemampuan siswa dalam silogisme. Pada kelas eksperimen memiliki rata-rata hasil nilai yang lebih tinggi dibandingkan dengan kelas kontrol. 


\section{DAFTAR PUSTAKA}

Dimyati, \& Mudjiono. (2009). Belajar dan Pembelajaran. Jakarta: PT Rineka Cipta.

Hosnan, M. (2014). Pendekatan Saintifik dan Kontekstual Dalam Pembelajaran Abad 21. Bogor: Ghalia Indonesia.

Mundiri, H. (2008). Logika. Jakarta: PT Raja Grafindo Persada.

Priyatni, E. T. (2014). Desain Pembelajaran Bahasa Indonesia Dalam Kurikulum 2013. Jakarta: Bumi Aksara.

Romauli, M. (2013). Pengaruh Pembelajaran Matematika Realistik Dan Berpikir Logis Terhadap Hasil Belajar Matematika Siswa SD Bharlind School Medan. Jurnal Tematik, 3 .

Setyono, Y. A., Sukarmin, \& Wahyuningsih, D. (2013). Pengembangan Media Pembelajaran Fisika Berupa Buletin Dalam Bentuk Buku Saku Untuk Pembelajaran Fisika Kelas VIII Materi Gaya Ditinjau Dari Minat Baca Siswa. Jurnal Pendidikan Fisika , 118.

Sugiyono. (2012). Metode Penelitian Pendidikan. Bandung: Alfabeta.

Widiadnyana, Suastra, \& Sadia. (2014). Pengaruh Model Discovery Learning Terhadap Pemahaman Konsep IPA dan Sikap Ilmiah Siswa SMP. e-Journal Program Pascasarjana Universitas Pendidikan Ganesha , 1. 